\title{
Znaczenie rzek i cieków wodnych dla poziomu życia mieszkańców miast na przykładzie Łodzi, Wiednia i Mainz
}

The importance of rivers and watercourses for the quality of living in the city on the example of Lodz, Vienna and Mainz

\section{Streszczenie}

W artykule zaprezentowano wyniki wieloletnich badań autorów nad znaczeniem rzek i cieków wodnych dla poziomu życia cjami obejmowaty zagadnienia dotyczace programów, ich zasadności, możliwości odtworzenia otwartych, przyrzecznych te renów publicznych przy kszattowaniu zrównoważonego klimatu miasta, poprzez wplecenie dolin rzecznych w jego strukture Atrakcyiność krajobrazowa regionu tódzkiego wynika z kontrastu między dolinami cieków wodnych, a wielkomiejską strukturą XIX wiecznego ośrodka przemysłowego. Doliny te nadały aglomeracji miejskiej wraz z miastami satelickimi szczególny charakter polegający na przenikaniu się obszarów zabudowanych z terenami urzadzonej zieleni parkowej oraz naturalizujacymi się licznymi dolinami cieków, tworzących układ o kształcie kręgu z promieniśćie rozchodzącymi się otwartymi terenam zielonymi.

\section{Summary}

This article presents the results of the author's many years of research on the importance of rivers and watercourses for the quality of living in modern cities on the example of Lodz, Vienna and Mainz. The research projects along with concept design covered the validity of programmes, possibilities of of restoring open near river public areas while shaping a balanced city climate through integrating iverbeds into its structure. The appeal of the Lodz region landscape emerges from the contras between watercourses and urban structure of the 19th century industrial center. Waterbeds (along with satellite towns) added a certain character - the urban area intertwines with planned park areas as well as a number of watercourses, creating the shape of a circle with open green areas radiantly extending form the center.

Stowa kluczowe: rzeki Łodzi, Ren, Dunaj, mikroklimat dolin rzecznych

Keywords: Lodz rivers, Rhine, Danube, riverbed microclimate

Miasto Łódź jako ośrodek przemysłowy rozwinęło się w połowie XIX wieku. Wyjątkowo dynamiczny, nagły rozwój spowodował obok wielu pozytywnych zjawisk wpływających na wzrost znaczenia miasta, polegającego na rozwoju zakładów przemysłowych, budynkow mieszkalnych, transportu kolejowego i układu ulic, pojawienie się charakterystycznych elementów dla okresu wybuchu rewolucji przemysłowej. Zjawisk negatywnych dla równomiernego rozwoju, tak charakterystycznego dla wielu miast których rozwój następował na przestrzeni wielu wieków. W Łodzi nie rozwinęły się struk-
The city of Lodz (industrial center) developed in the middle of the 19th century. A very dynamic growth caused the appearance of characteristic signs of the industrial revolution (along with other positive outcomes such as the increase of the cily importance, new buildings, public transport, etc.). Signs which were negative for a balanced development, which took place in other cities through many ages. No typical urban structures were constructed. In a city with profit in mind, nobody thought about provid- tury typowe dla mieszczaństwa. W mieście nastawionym jestruktury przeznaczonej dla zdrowia, nauki, wypoczynku czy rekreacji. Realizowano to w minimalnym zakresie, jedynie dla zapewnienia ciągłości pracy zakładów przemysłowych. Pierwsze tego typu obiekty i przestrzenie powstały na przetomie XIX i XX wieku. Prawdziwy rozwój myśli kształtujące strukture dojrzałego miasta nastapit po odzyskaniu niepod ległości i podniesienia todzi do rangi mizsta wojewódzkieeo Szczéśiwie potożenie miasta z jego licznymi rzeczkkieciekami, sta p i zozlewiskami oraz pozostałościoczkami czy tódzkiej tak chêtnie i grabizzo wykorzystywanyi puszczy lodzkjo okres eksplozj czony i juz w laph 20 tych ubieglego wieku zostal zauwazony przez projektantow ukladu przestrzennego aglomeraci lodzkiej. Podjęto wówczas proby uporządkowania i wykorzystania otwanych terenow zielonych polożonych wzdłuz lini rzek i zbiorników wodnych. Ostatnie lata ubiegłego stulecia i początek nowego XXI wieku dają realną szansę realizacji rozległych planów związanych z rekreacyjnym wykorzystaniem bogactwa zastanego układu geograficznego, wpływającego jednoznacznie pozytywnie na standard życia w mieście. Autorzy pragną poprzez porównanie trzech przypadków na którymi prowadzili badania porównawcze tj. układów Wiedeńskiego Dunaju, Mogunckiego Renu i 18 rzek Łodzi przedstawić, róznorodne podejścia do projektow wykorzystania układu występowania akwenów, cieków wodnych w mieście. Rożnorodne zarówno jeśli chodzi o historyczne dziedzictwo jak i sposób realizowania w/w projektów dzięki decyzjom administracyjnym, programom rządowym, regionalnym czy też lokalnym, zależnym od aktywności mieszkańców.

Pierwszą rozważaną sytuacją porównawczą jest przepięknie udomowiony" Dunaj, rzeka biegnąca przez wiele krajów Europy, która wszedzie poprzez zrównoważony sposób zagospodarowywania wpływa kojaco na mieszkańców dajac im nie tylko niezanomiane widoki, ale tez konkretnie wptywajac na warunki klimatyczne. Długość Dunaju to okoto 1300 kilometrów. W poblizu granicy pástwowej Austrii ze Stowacja Dunaj biegnie prez stolice, Wiedeń. Rzeka stworzyła z miaDunaj biegnie prez stolice, Wón. Rzeka stworyla z mia-

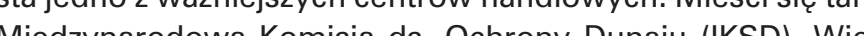
deńczycy, by odpoczac, udaja sie nad Sury Duna cay plaze denczycy, by odpoczać, udaja się nad Stary Dunaj czy plaże Copa Cagrana na Wyspie na Dunaju. Woda przyciąga pływakow, zeglarzy, whoslarzy, surfingowców czy rowerzystow ispacerowiczów. Trzydniowa coroczna impreza Donauinselfest $z$ około 3 milionami uczestników to największa, darmowa impreza na świeżym powietrzu w Europie. W okresie letnim, prawie 190 tysięcy osób dziennie odwiedza Wyspę na Dunaju, jej 70 hektarów łąk, 180 hektarów lasów z milionami drzew ikrzewów. Kanał Donaukanal, zwany także "Małym Duna jem" powstał w wyniku regulacji Dunaju w latach 1870-1875. Przepływa obok wiedenskiej starowki. Kilka stacji metra od centrum miasta mieszkańcy wysiadają nad rzeką w enklawie zieleni i przepięknych widoków. Stary Dunaj jest dawną odnogą Dunaju, ze względu na czystą wodę i bliski pierwotnemu kształtowi brzeg, jest bardzo lubiany wśród wiedeńczyków, którzy korzystają z uroków lata nad jego wodami. Miasto zało- ing health, education or relaxation opportunities. industrial complexes was taken care of. First buildings of this kind were constructed between 19th and 20th century.

The real emergence of modern city shaping thought hapened after regaining independence and the elevation of the city of Lodz to the rank of the regional centre. Fortunately, the location of the city with its many streams, watercourses, ponds, overflow areas and remains of the Lodz forest (exploited during the capitalist period) did not go to waste and in the 1920 s was noticed by city pla designers. During that time there was an attempt t regulating and using the open green areas (along the rivers and water reservoirs). The last years of the previous century and the beginning of the 21 st century provide a real chance to create extensive plans for recreational use of the wealth of this geographical position, which positively influences the living standard in the city.

The authors (through the comparison of three researched cases - The Vienna Danube, The Mainz Rhein and 18 Lodz rivers) want to present various approaches to the existing designs for using the system of waterbeds in the city, which is diverse from a historical point of view as well as the manner of realizing these projects on the basis of administrative decisions, government programs (regional or local), based on the resident activity. The first comparison is the Danube River, which flows through many European countries. It is well managed and positively influences the inhabitants, providing them not only with a pleasant view but also influencing the local climate. The length of the river is around $1300 \mathrm{~km}$. Near the border between Austria and Slovakia it flows through the capital, Vienna. The river turned the city into one of the more important commercial centres. It houses The International Commission for the Protection of the Danube River (ICPDR). The residents relax on the Danube Island (Copa Cagrana beach) or visit the Old Danube. The Old Danube attracts swimmers, sailors, rowers, surfers, cyclists and strollers. The Donauinselfest, with around 3 million participants is the biggest, outdoor free event in Europe. The island consists of $42 \mathrm{~km}$ of meadows, sand and gravel beaches, swimming bay, playing fields, boat, water cycle and surf board rentals. During the summer period, almost 190 thousand people visit the island on a daily basis. The island consists of 70 ha of meadows, 180 ha of forests and 1.8 million trees and shrubs. An information center was opened in 2010. The Donaukanal ("Little Danube") was created due to the river regulation between 1870 and 1875. It flows next to the Vienna old town. A number of metro stations from the city center, the inhabitants can enjoy the river in an enclave of greenery and pleasant views. 
żyli Rzymianie uważając jego lokalizację za wyjątkową zarówno pod wzgledem polożenia w rejonie rzeki, jak i ze wzgleedu na mikroklimat i różnorodność przyrody wokół. Źródła rzeki są na terenie Niemiec w górach Schwarzwald, a ujście w Morzu Czarnym na obszarze Rumunii. Jest bardzo atrakcyjna pod względem turystycznym Wzdłuż jej biegu jest wiele parków narodowych i krajobrazowych, w tym Park Narodowy Donau - Auen w Austrii. Aby zabezpieczyć miasto przed powodziami, powstał dodatkowy kanat, równoległy do gtómnowodziata rzeki tzw. Nowy Dunaj. Stworzono wówczas wyspe. Stopniowo misto powiekzato Stopniowo miasto powiększało się obszarowo, za rzeką powsta nowoczesny kompleks wiezowcow zwany UNO City. Nowy Dunaj ograniczony jest wieloma tamami i jest przepływowy tylko w przypadku zagrożenia powodziowego. Wody Dunaju należą do najczystrych. Wyackowe walory smakowe posiadá rón do na wiedens ka woda żodlana Hoch suellwasser, która również ma swoj udzial w zapewnieniu Wiedniowi pierwszej lokaty $w$ rankingu jakossci życia. Oficjalne potwierdzono to w studium Mercera z 2012 r. Ponadto miasto czwarty raz zajeło pierwsze miejsce $w$ światowym rankingu miast, w których
żyje się najlepiej. Natomiast w październiku 2012 raport ONZ pt. "State of the World's Cities Report 2012/13" potwierdzit, że Wiedeń jest miastem, którego mieszkańcy cieszą się największym dobrobytem na świecie. Oceniając tę wartość wzięto pod uwagę także jakość życia, infrastrukturę i ekorozwój. Przez mieszkańców zostało nazwane zielonym. Zabytkowe Śródmieście kusi wieloma parkami. Zielony Wiedeń ma wiele rodzajów terenów zielonych, od dokładnie zaprojektowanych rabatek po bujną gęstwinę lasu. Nie bez powodu Las Wiedeński na zachodnim krańcu miasta, podobnie jak w todzi Las Łagiewnicki, nazywa się „zielonymi płucami” miasta. Obszar ten jest uznany przez UNESCO jako rezerwat biosfery. Jego naturalny krajobraz obejmuje $1350 \mathrm{~km} 2$ powierzchni zamieszkanej przez wiele gatunków zwierzą i roślin. W Wiedniu jest również wiele punktów widokowych, łatwo dostepnych dzieki komunikacii publicznej, takich jak Wieża Dunajska KahlenKi koż wien pukow wid kowych, Kawo dosẹnch berg, Cobenzl. Naśwa się analogia z Lodzią i jej Rudzką Gorąa.

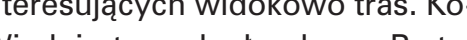
lejne bog cho zielonego u, óm a glowna a a a, oddanego wedenczykom do uzyku przez cesarza Jozefa oll Na wsch Lobau, stanowiąca częsc Parku Narodowego Łęgow Naddunajskich. Jest to jeden z największych obszarow zalewowych Europy Srodkowej. Park narodowy rozpościera się od wyspy Lobau w granicach Wiednia do ujscia rzeki Morawy. Zyje w nim kilkadziesiąt gatunków ryb, ssaków i ponad 100 gatunków ptaków. Powstanie Parku Narodowego Donau-Auen zostało zainicjowane przez protesty obywatelskie przeciwko planowanej budowie elektrowni wodnej w latach 1983/1984, uratowały one ęgi przed zniszczeniem. W 1996 na terenie tęgów utworzono park narodowy. Obecnie parkowi narodowemu zagraża planowana droga ekspresowa przez Lobau. Ma ona co prawda w przeważającej swej długości przebiegać tunelem pod parkiem narodowym, niepokoi duża liczba planowanych budowli nadziemnych. Specjaliści twierdzą, że
The Old Danube is an old branch of the Danube River. Because of clean water and the shore, whic is similar in shape to the original shore, it is very popular among people, especially during summer. It is possible to take a boat trip as well. The city was built by the Romans, who saw the benefits of the location - many rivers, microclimate and varied nature. The Danube River is the second longest river in Europe - it flows through ten countries. The source is in Germany, in Schwarzwald Mountain and the estuary in The Black Sea in Romania. There are many national and landscape parks along the river, such as The Danube-Auen National Park in Austria. In order to protect the city from floods, another canal was created, parallel to the main riverbed, the so called New Danube. The Danube Island was created as well. Slowly the city expanded and UNO City, a modern skyscraper complex was created beyond the river. The Danube River, which was once an inspiration for Johann Strauss and his famous waltz, no longer exists. The New Danube is regulated with many dams and free flow is only possible during flood conditions. Vienna has such clear tap water that it can be drank safely. The Hochquellwasser (Vienna spring water) is so healthy that it had its part in helping Vienna obtain 1st place in the Quality of Living competition. It was officially noted in Mercer's study from 2012. Furthermore, the city was chosen for the fourth time as the best place to live in the World City Rank. In october 2012, the UN "State of the World's Cities Report 2012/13" validated Vienna as the bes place to inhabit. A number of factors were take into account, such as the quality of life, infrastructure and eco-development. The inhabitants call it "The Green City". The historic city centre is filled with parks. The Green Vienna has many natural areas, from carefully designed flower beds to thick forests. It is no wonder, that The Vienna Forest in the west, similar to the Lodz Łagiewnicki Fores is called the "green lungs" of the city. This area is recognized by UNESCO as a biosphere reserve. It covers $1350 \mathrm{~km} 2$ where many species of plants and animals live. There are also many viewpoints in the city (easily accessible with public transport), such as: Danube Tower, Kahlenberg, Cobenzl. An analogy to Lodz and Rudzka Góra. Cycling, strolling and cross-country skiing is popular due to well marked routes. There is also The Prater - a vas green area with a $4,5 \mathrm{~km}$ main avenue - given to Vienna inhabitants by the emperor Joseph II. In the east is the Lobau plain, a part of the Donau-Auen National Park. It is one of the biggest floodplains in Central Europe. The park stretches from the Lobau Island within the Vienna border to the Morava River estuary. It is home to dozens of species of fish mammals and over one hundred different birds. The creation of the Donau-Auen National Park was started by citizen protests against the building of

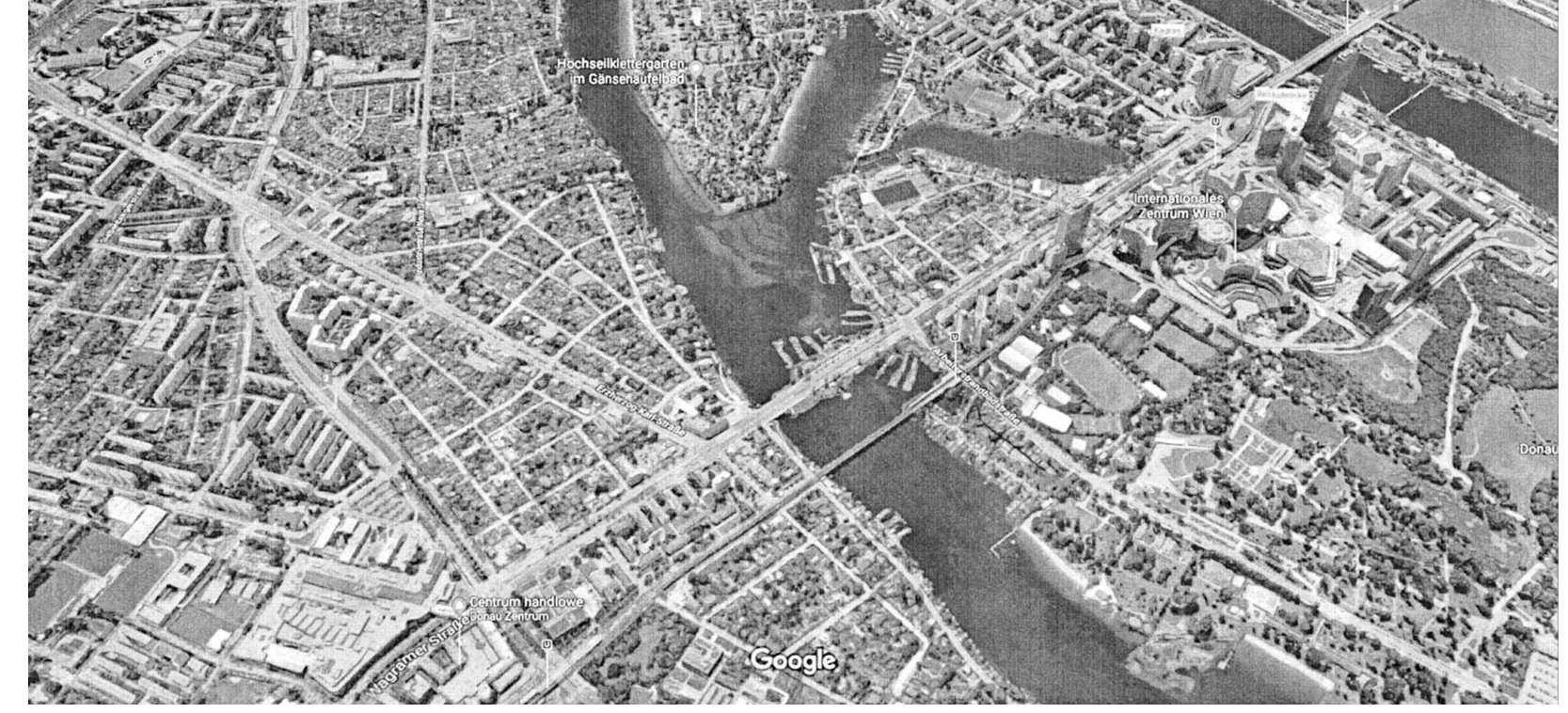

il. 1. Dunaj w Wiedniu. Zdjecie lotnicze Google Maps / Danube River in Vienna

może to spowodować zniszczenie systemu wodnego ważnego dla łęgów naddunajskich. Wiedeńczycy mają nadzieję, że w trakcie konsultacji społecznych, podobnie jak z Łęgami tak z tą inwestycją uda się rozwiązać sprawę zgodnie z zasadam zrównoważonego rozwoju, zachowując unikatowe wartości rejonu. Kilka istotnych informacji na temat zawartości i potencji zespołu wiedeńskiego nazwanego Zielonym Wiedniem. Na obszarze tym zajmującym $50 \%$ terytorium miasta jest około 850 parków, wielki teren obejmujący Zielony Prater to $6 \mathrm{mln}$. m2 powierzchni. Są też: ogród botaniczny z kilku tysiącam gatunków roślin alpejskich $w$ ramach ogrodu alpejskiego, rezerwat biosfery Las Wiedeński o powierzchni $1350 \mathrm{~km} 2$ z bogactwem gatunków roślin i zwierząt. W ramach terenów zielonych miasta, władze Wiednia podają liczbę zieleni wysokiej w ilości ponad 600 tysięcy drzew. [il.1.]

Kolejnym wspaniałym przykładem jest dorzecze rzeki Ren biegnącej poprzez Szwajcarie, Niemcy, Lichtenstein, Austrie, Francje i Holandię. Długość tej pięknej rzeki to $1233 \mathrm{~km}$, powierzchni to 224 tysiace $\mathrm{km} 2 z$ źródłami w Szwajcarii $\mathrm{Naz}$ wierzch zeki, jak podaja doeuro ezaczacacego poruszac się, . pokonuje Jezioro Bodenskie, dalej na pónnoc tworzy granic

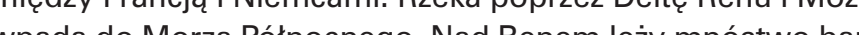
wpada do Morza Pól nocnego. Nad Renem leży mnóstwo bardzo znaczących whistorii Niemiec i Europy miast między innymi: Konstancja, Strasburg, Mannheim, Moguncja, Koblencja, Kolonia czy Rotterdam. Szerokośc Renu, przed Moguncja (Mainz) to około $500 \mathrm{~m}$, dalej rzeka osiąga nawet 1 kilometr. Odcinek pomiędzy Bingen a Koblencją słynny jest $z$ wielu zabytków średniowiecznej architektury, winnic i zamków, wpisany został w 2002 na listę swiatowego dziedzictwa UNESCO. Od Bonn Ren jest już szeroką rzeką nizinną. Ogromną ilośc turystów przyciągają też zamki na górach Drachenfels. U niemieckiego kompozytora Richarda Wagnera w tetralogii Pierścien Nibelunga rzeka Ren jest epizodycznym bohaterem, jak tez areną przedstawionego świata. Naukowcy z Uniwersytetu w Tybindze oraz z Instytutu Seckenberga we Frankfurcie nad Menem, doszli do wniosku, że rzeka Ren jest o pięć milionów lat starsza niż myśleli. Potwierdzenie uzyskano dzięk a water plant between 1983 and 1984, which saved the breeding grounds from destruction. In 1996 the park was created. Presently, the park is endangered by a planned express road through the Lobau. It is supposed to be constructed mostly under the park, but with a large number of ground leve buildings. Specialists claim that it could destroy the water system important for the breeding grounds, The inveriqu ers $50 \%$ of the complex. This area, which coverro $50 \%$ of the city territory, contains around 850 parks, the huge Prater area is $6 \mathrm{~m} \mathrm{~m} 2$. Furthermore, there is a botanic garden (several thousand alpine the alpine garden), the Vienna For(a) (1) 600 thousand trees. [ill. 2]

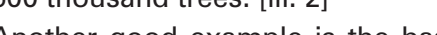
Anver ichtenstein, Austrive (ive 列 $1233 \mathrm{~km}$, area is 224 thousand $k$ 2, with sources in Switzerland. The name, 列 to move or to is the Lake Rhine originates in the Swiss Alps, next is the Lake Constance (Bodensee), further north it crester and the the Strasber

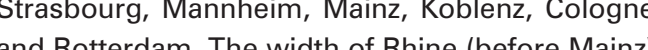
(before Mainz) The $500 \mathrm{~m}$, further it can even reach $1 \mathrm{~km}$. Th section between Bingen and Koblenz is known for From Castles in the Drachenfels Mountains attract a lot 
znaleziskom skamielin w najbardziej malowniczym odcinku w odległości mniej wiejcej $30 \mathrm{~km}$. Mainz to miasto położone cę landu Nadrenia-Palatynat z liczba mieszkańców około 200 tys., z czego około 40 tys. stanowią studenci. W pobliżu Mainz są równie interesujące miasta jak: Wiesbaden, Koblenz, Marburg. Miasto Mainz, założone w starożytności, znane później z wynalezienia druku. Mieszkańcy szczyca się wspaniałym klimatem, przepieknymi bulwarami nadrzecznymi ciagnacymi sie matem, przepięknymi bulwarami nadrzecznymi ciągnącymi się całymi kilometrami wzdłuz dzielnic, dając mozzliwosc rzeszom mieszkan ow bezpossedniego kontaktu z mikroklimatem rzeki: Muzeun Gutrą, zamkiem elektorów i wielom pozt przez całą noc tętni życie rozrywkowe, szczególnie w święta i okresy letnie. Ren zawsze mial ogromny wptyw na poziom życia mieszkajacycych nad nim ludzi. Wzdłuż Renu rowerzyści moga podazzad szlakiem jego historii i kultury, od zrodel w Alpach, aż po wybrzeże Morza Północnego. O znaczeniu Renu najlepiej świadczą wielkie budowle ciągnące się wzdłuż jego biegu: zamki, twierdze, kościoły i historyczne miasta. Wiele z nich znajduje się na liście światowego dziedzictwa UNESCO. Ren jest również ważną arterią transportową. Rzeka jest jedną z najbardziej zanieczyszczonych mikroplastikami. Ostatnio pod kątem mikroplastików naukowcy z Uniwersytetu w Bazylei przebadali jej wody. Pobrano próbki w 11 miejscach, na odcinku o długości ponad $800 \mathrm{~km}$. Mikroplastików wyjątkowo dużo było $w$ wierzchnich warstwach wody na odcinku pomiędzy Bazyleą w Szwajcarii a Rotterdamem w Holandii. Minimalne średnie zanieczyszczenie stwierdzono $z$ kolei na odcinku pomiędzy Bazyleą a Moguncją w Niemczech, gdzie stwierdzono jedynie ponsd 200 tysięcy cząsteczek na km2.. Średnie stężenie mikroplastików w próbkach z Renu jednego dnia to ponad 191 milionów czastek polimerowych. To najpilniejszy problem do rozwiązania. [il. 2.]

Rozdrobnienie struktur społecznych stwarza potrzebę przebudowy społeczeństwa zurbanizowanego. Miasto jako rezultat ogromnej ilości poszczególnych działá zánno publicznyta jak i pryw losch, budynek czy grupa budynków, oddziach wak i ferze estetycznj jak i funkcjon W i ralnym środowiskiem. Fundamentalne funkcje miasta musza

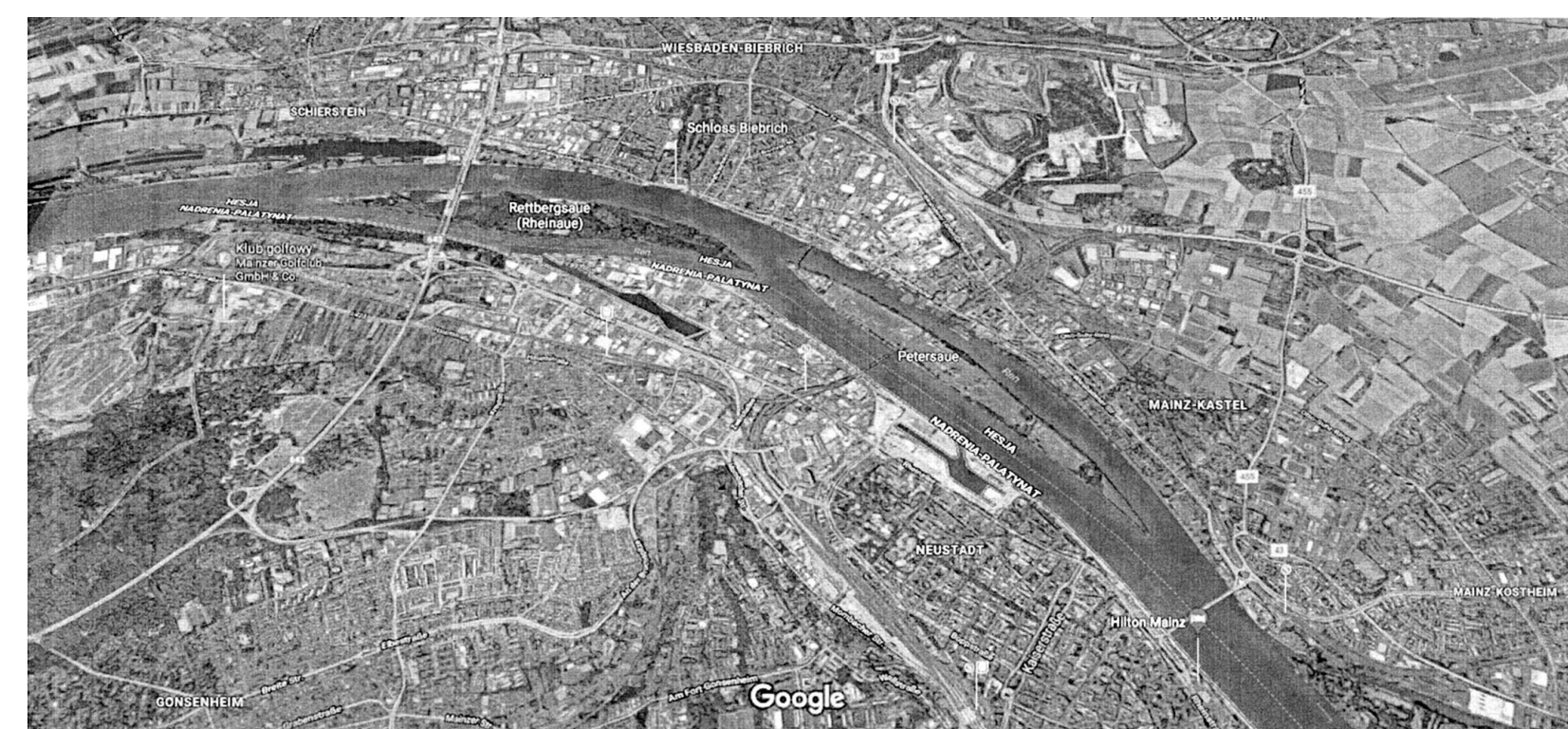

W łatwy sposób być dostępne a jego środowisko może być wienie dostepu do niające pracę, zabawę i wypoczynek. Uladzenia cześci miast, również poprzez wykorzystanie przestrzen zielonych i rzecznych jest nieuchronne. Dostęp do terenów wybrzeży lub atrakcyjnych krajobrazowo, dla jakości życia jest bardzo ważny. Rada Architektów Europy zaleca: „Europejskie mia sto jest jedynym najbardziej znaczacym zbiorowiskiem naszej wspólnej spuścizny kulturalnej i jako symbol kwintesej nas wspolnej spuscizny kulturalnej i jako symbol kwintesencją europejk struktu sobyateli poprzez organzaje suzozliwiając im wspó uczestnictwo w sposób racjonalny, demokratyczny i naprawd nitur miast w whi sposob, aby wlasciwie rozwiązywać problemy, z punktu widzenia lokalnego Klimatu i tradycji, uzyskać spójny obraz calosci. Stuzy temu postęp w inzynierii ruchu, kontrol hałasu i czystości powietrza, wtopienie układu zieleni, cieków i zbiornikow dając pozytywny efekt dla społeczności. Europejskie zalecenia zawarte w Białej Księdze oceniają stan istniejący inakazują nam projektantom i nam mieszkańcom jak najszybsz podjęcie starań, bowiem: „Wskaźniki określające intensywność zabudowy przeciążają infrastrukturę centrów miast, niszczą historyczną skalę i wypełniają zabudową każdą wolną przestrzen a nie są w stanie uporządkować chaosu komercyjnej zabudowy, ktora obrasta dojazdy do wielu miast. Miasto zrównoważone to kluczowy cel jaki trzeba uzyskać." ${ }^{2}$ Projektanci, powinn promować poprawę mikroklimatu poprzez wyraźne zwiększenie udziału zieleni, terenów otwartych i zbiorników wodnych czy cieków, rewitalizować zniszczone krajobrazy i poprzez dobre praktyki projektowe dokonywać ich powiększenia, zbliżenia do miejsc egzystencji oraz dokonywać ich regulacji.

Działalność polegająca na przygotowaniu projektu pozyskania struktur zielonych przestrzeni jest prowadzona w oparci odpowiednie regulacje prawne, pamiętać trzeba o przygotowaniu ofert ułatwień finansowych oraz lokalnych programów rewitalizacyiny tak aby udato sie pokoná bariery własnościowe dzieki dziata som spóćci miejk bariery mash programów pozyskujacych właścicieli terenów. Gtów-

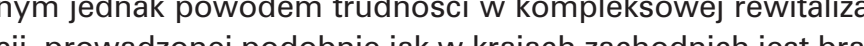
cli, prow dzonej podo nie jak w k komp zachodnich jest brak cric gdzie partnerstwo publiczno-prywatne jest charakterystyczn cechą prowadzonych procesów rewitalizacyjnych a zadani podzielone przez partycypujących partnerów tak jak na przykład w Wiedniu czy Mainz gdzie procesy mogły zostać zdynamizowane i prowadziły do realizacji programów w krótkim czasie co daje już dziś oczekiwane efekty. My będziemy zapewne musieli dłużej poczekać na efekty działań, stąd musza być one szczególnie dokładnie przemyślane, tak aby nie uronić niczego z istniejących zasobów. Miejscy eksperci zwracaja uwagę, iż należy mieć także świadomość, że silnie oddziaływac mogą innego rodzaju bariery, m. in. polityczne, mentalne, instytucjonalne, jak rowniez bariera dochodowa, klima interesów czy też konkurencja w użytkowaniu ziemi. Kolejne utrudnienia to brak wspólnej, strategii rozwiązywania problemów o charakterze społeczno-gospodarczym i przestrzennym. this river carries over 191 million polymer particles into the North Sea. And we are only talking abou the surface waters". [ill. 2]

Fragmentation of social structures creates a need for rebuilding the urban society. City, a result of many different activities, both public and private, building or a complex, influence the aesthetics as well as function. It is important for the surroundings to provide good quality space, which is connected with natural environment. Fundamenta city functions must be easily available and the environment can be silent or loud, to make work entertainment and rest easy or difficult. Providing easy access to the most valuable (from a cultura point of view) city parts also with the use of green and river areas is unavoidable. Access to the shore or pleasant views is very important for the quality of life. Architect's Council of Europe recommends: The European city is one of the most importan sums of our cultural heritage and a symbol of the European culture. Our citizen tradition tries to make the social structure clear and available for citizensthrough managing a constructed environment, allowing them to take part in a rational, democratic and truly human way." We must take care of the cultural continuity of city shaping in a way, that it is easy to solve problems (from the poin of view of the local climate and tradition), in order to obtain a complete picture. It is served by progress in transport engineering, noise control and air purity - incorporating greenery, watercourses and reservoirs with a positive effect for the whole community. The European recommendations in The White Book assess the current conditions and urge us the designers as well as us the inhabitants to take up activity: "The indexes of the construction intensity overstrain the city centre infrastructure, destroy the historic scale and fill every free space with new buildings while not being able to control the chaos of commercial construction, which overgrows approaches to many cities. A balanced city is the key goal to achieve". Designers should promote improving the microclimate through the increase of greenery, open spaces and reservoirs or watercourses, restore the destroyed landscape and through good design practices make them bigger and more regulated.

The activity to prepare a design of green space structures is based on legal regulations. It must be remembered to prepare financial aid offers and local restoration programmes to defeat the owner barriers. Thanks to urban community activity in projects - they help to persuade the land owners. Main reason for this restoration is the lack of funds (similar to the western countries). Furthermore, in European cities, where public - private partnership is a distinctive feature of restoration processes and tasks are divided among the partners like in Vienna or Mainz, which shortened the 
Proces przeciwdziałaniu rozrastania się miasta na otwarte obnku zrównoważonego rozwoju jego struktury, daje podstawy do pozyskania kolejnych przestrzen ku realizacji powierzchni rekreacyjnych polepszających warunki życia. Mamy też problem w zasadzie nie występujący w przykładach z zachodniej Europy związany z zasilaniem migracyjnym miasta. W Łodzi odpływ mieszkańców jest bardzo widoczny, co mieć bedzie istotne znaczenie dla przyszzego programu przeobrażeń i strategii rozwoju. Kreowanie wizerunku miasta jego atrakcyjnósi poprzez tworzenanie wizerunku miasta, jego azrakcy nosci, poprzez tworzenie ekologicznej struly, nych, by, opwane nazunkami zyciawien na przyciągnęcie nowych mieszkanców. Kreowanie jego wize-

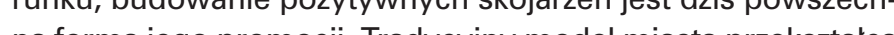
ną forma jogo promocj. Tradycyny model miasta przeksztaica się $\mathrm{W}$ kierunku postrzegania jego walorów z pozycji bardziej turysty, widza dla ktorego znaczenie maja struktura zabudowy, kliny zieleni, kręgi wartości kulturowych i w końcu zielone centrum petne zieleñców $i$ historycznych parków dostępnych powszechnie. Bardzo ważne jest położenie miasta w ramach państwa, tutaj Łódź jest wyjątkiem na skalę Europy. Komunikacyjna dostępność całej Europy, jednocześnie z biologiczna czystą klimatycznie rzeczywistością.

W Łodzi i okolicach oznakowano szereg szlaków turystyki pieszej i rowerowej, umożliwiających aktywny wypoczynek w połączeniu z poznawaniem atrakcji regionu. Obecnie na terenie miasta płynie 18 rzek o łącznej długości około 110 kilometrów. Zlewnie Łodzi to: dorzecze Bzury, dorzecze Miazgi, dorzecze Neru. Oto zalecenia szczególnie istotne dla tworzenia przy- time needed for completion with expected results seen today. We will probably have to wait for the effects, therefore they must be well planned so the available resources are not wasted. Urban experts warn, that there may be other strong barriers, such as political, mental, institutional, as well as financial, business climate or competition in land usage. Further difficulties include lack of common strategy in solving spatial and social-economic problems. The process of counteracting the city expanse to outer open spaces in the direction of a balanced structure development provides basics for obtaining more open spaces for recreational purposes. There is also an issue not present in western Europe, which is emigration. In Lodz this is especially evident, which will impact the future plans of city shaping and development. Creating the city image, making it more attractive through ecological structure based on immaterial senses experience, building positive connotations with living conditions is very important to attract new inhabitants. Creatin a positive city image is a common promotion strategy today. The traditional city model is changing into noticing its advantages from a tourist point of view, who cares more about the building structure, greenery, cultural values and finally a green centre full of widely available historic parks. The location of a city in the country is very important - Lodz is an exception in Europe - availability and transport to the whole of Europe and at the same time a biologically clean climate reality.

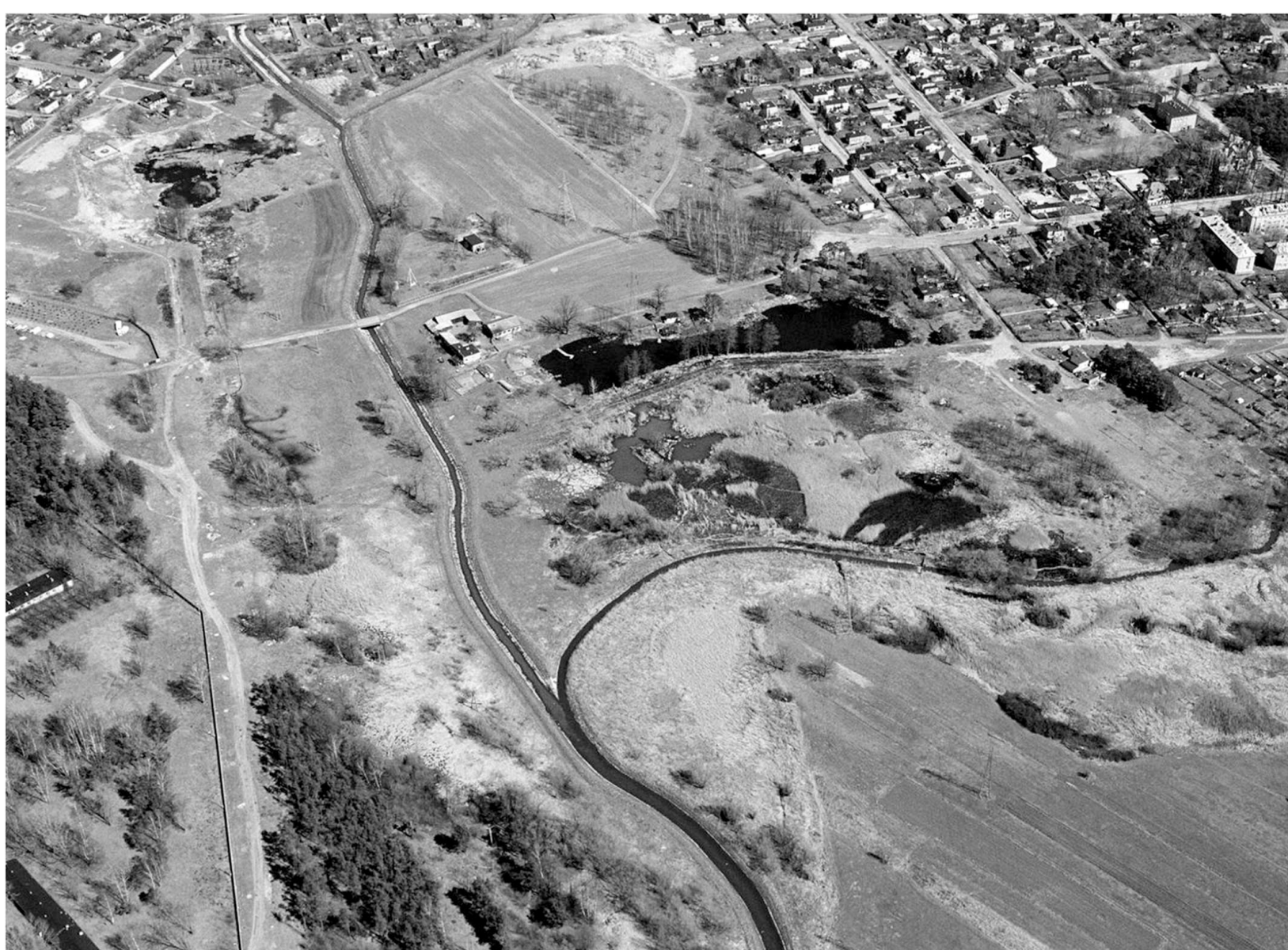

szłego przestrzenno-biologicznego zrównoważonego obszaru Łodzi. W ramach studium poświ sując programy i określając hasłowo główne działania w postaci: Parki, lasy, tereny zieleni urzadzonej, parki dydaktyczne, przestrzenie zielone dolin rzecznych denaturalizowane, ogrody działkowe. Antropopresja terenów leśnych ze względu na występowanie w obszarze aglomeracji. Idea błękitno - zielonej sieci, stanowi rozwiniecie ksztattujacego sie już systemu Ziejone sieKrẹgu Tradycji i Kultury. Ochrona tożsamości i wizerunku . Strefa ochrony krajobrazu - zabytkowych parkow i cmentarzy Dobra kulury wspóc nikacja row i powiązan. Obszary wymagające rekultywacji, przekształcen Architekture można pojmować w sposób rygorystyczny oraz Architekr e mozna pojmować w sposób rygorystyczny oraz szerszy - poprzez studiowanie, albo rozważną praktykę budowlana. Na czym więc polega jej prawda lub przeciwienstwo? t tak jak most jest po pierwsze tylko w malej części symbolem w znaczeniu ze wyraża cos, co w scisły sposób do niego nie należy. Jeśli tak rozumiemy most, to nie pojawia się on jak ekspresja. Zawsze będą ludzie, którzy wykorzystają most jako "zwykłe przejście przez rzekę" - nie postrzegaja go jako twórcy miejsca, sposobu na uczłowieczenie ich środowiska i formowanie ich świata. Na każdym kroku, myślenie jest potwierdzon jako skladnik mieszkania. Architektura jest aktywnym składnikiem w osiągnięciu przyjaznego miejsca pobytu. Wykształcony architekt czy laik powinien przemyśleć pożądany efekt budowania. Architekci uczą się systematycznie zasad regionalnej architektury. Poszukiwanie pierwszej, pełnej architektury trwa przecież od Witruwiusza. W końcowej ocenie forma i wyraz idealnie służą ostatecznemu celowi. Technologiczny postep ciągle stwarza nowy kontekst w którym postrzegamy swoje środowisko i w nim żyjemy. Budynki jako obojętne wzgledem lokalnych warunków, jako obraza tego co można nazwać porządkiem rzeczy na świecie - bez znaczenia czy ktoś sądzi że ządkiem rzeczy na swiecie - bez znaczenia czy koś sądzi że jest to czessc jakiegos boskiego planu czy nie. Piękne bezpreensjonalne przeszłe konstrukcje, ktore wydają się dostosowano do do tego pryzuczilsmy zo terajo obycie zechnologia wy daje sie byc koniecznym warunkiem uzyskania rón naturalne srodowisko pelne zieleni, akwenow wodnych czy ciekow ktore wplywając na mikroklimat korzystny dla człowieka dają mu niepowtarzalną szansę zdrowego zycia.

W Łodzi realizowany jest kompleksowy program o charakterze koncepcyjnym polegający na zapewnieniu łączności róż nym przyrodniczym elementom miasta, mają one zapewnic również dostateczną ich ochronę. Jednym z najstarszych ciągle nie mogących osiągnąć stosownej rangi to Zielony Krąg Tradycji i Kultury opracowany po raz pierwszy w 1993 rok wraz z Planem Zagospodarowania Przestrzennego Miasta Łodzi. Tutaj najistotniejszą wartością była ochrona dziedzictw przyrodniczego wraz z historyczno-kulturowym. Idea to powiązanie struktur istniejących parków i zieleńców miejskich już wówczas traktowanych jako zabytkowe z rewitalizowan przestrzenią historycznych założeń fabrycznych i mieszkal-
There is a number of official tourist trails (strolling and cycling) located in and around Lodz wh be used for active rest with tourism. Currently there are 18 rivers of $110 \mathrm{~km}$ combined length in the city area. The Lodz river basins are: Bzura, Miazga an Ner. These are important recommendations for creating a future space - biology balanced Lodz area: Parks, forests, planned green areas, didactic parks, denaturalized river valley green areas, allotments. Anthropopression of forests due to urba vicinity. An idea of a blue - green network, which is an extension of The Green Circle of Tradition and Culture system (still being developed). Protectio of Lodz identity and image. Landscape protectio area - historic parks and cemeteries. Modern culture and greenery protection. Bicycle transport (also recreational), rules of shaping and connecting. Areas in need of maintenance, reshaping or restoring. Improving living conditions in the city. [ill. 3]

Architecture can be viewed rigorously and widely through study or careful building practice. So what is the truth and the opposite? As a bridg is firstly in a small part a symbol, in a way that it means something, which it does not possess. this is how we understand a bridge, then it does not exist as an expression. Bridge is an object and that is it. There will always be people who see a bridge as "a crossing through a river", not as a creator of a place, a method to humanize their environment and shape their world. With every step, thinking is validated as a dwelling ingredient.Architecture is an active ingredient in reaching a friendly place of stay. An educated architect or a layperson should think throug the desired construction result. Architects learn systematically the rules of regional architecture. The search for the first, complete architecture continues since Vitruvius. In the final verdict, the shape and the expression perfectly serves the final goal. Technological advancement constantly creates new context in which we see our environment and live. Buildings are indifferent towards local conditions - an affront to what can be called the order of things - whether somebody thinks this is a part of some Divine Plan or not. Unassuming future buildings, which seem adapted to the local climate. Depending on the the ability to catch up to technological advancement in society where we live - that is the ability to slowly back away from aphoristic judgements and becoming aware of the fact, that the state of things may be more complex than can be understood from a simple approach. Our time is the age of quick changes - for good or ill. It's been like that for at least two hundred years. We've gotten used to this by now. Ironically then, while we increase our knowledge of technology, we must find balance between what we add and what the natural envi- 


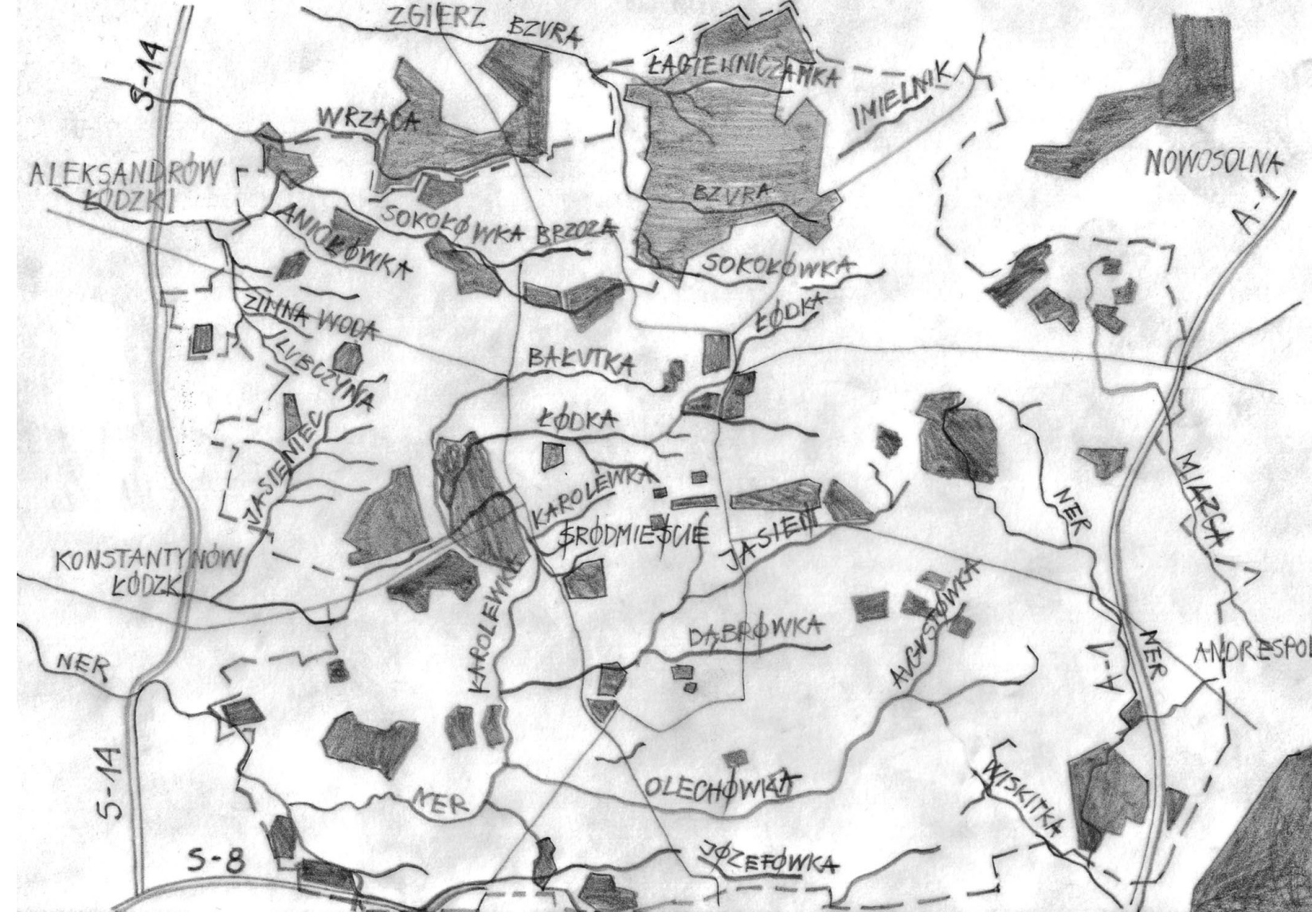

il. 4. Układ siecire
Lodz region

nych. W skład miały wejść tereny m.in. Manufaktury, Politechniki Łódzkiej, Księżego Młyna czy osiedla mieszkalnego Matwiłła Mireckiego wraz $z$ terenami Parku na Zdrowiu i terenu powojskowego Brus. W kolejnych latach rozważano realizacje projektu pod nazwą Zielone Skarby Łodzi przygotowanego w roku 2007 w ramach Studium Uwarunkowań i Kierunków Rozwoju Łodzi. W tym kręgu miały znaleźć się: doliny rzeczne (18), zespoły przyrodniczo - krajobrazowe (13), kompleksy leśne (4). Kolejny projekt to Błękitno - Zielona Sieć zintegrowanych terenów leśnych, miejsc rekreacyjno-wypoczynkowych i wszelkich terenów urzadzonej zieleni stużacym rekreaci mieszkańcom todzi Bedzie to w pełni rewitalizacyiny program o chrake

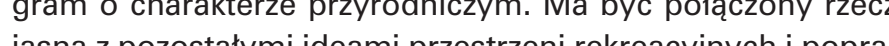
jasna z pozostaly prayrodiczym. Wa byc polaczony rzeczwiających standard życia w mieście. W Lodzi są cieki i rzeki nalezace do trzech zlewni. Bzury (Bzura, Lagiewniczanka, Sokolowka, Wrąca, Brzza, An Jowka i Zimna Woda), Miazgi (Miazga), Neru (Ner, Gatka, Jasień, Olechówka Augustówka, Karolewka, Łodka, Bafutka, Jasieniec, Dobrzynka).Idea ta ma powiązac tereny zieleni urządzonej tzn. parki ponad 500 ha powierzchni, zieleńce, cmentarze, ogrody działkowe, oraz 5 zespołów leśnych tj. Łagiewniki, Lublinek, Popioły, Żabieniec, Rokicie, 1350 ha powierzchni, tereny zespołów zabytków historycznych wraz z zespołami zawierającymi zabytki przyro$\mathrm{dy}$, to kolejne kilkaset ha powierzchni. Po wieloletniej realizacji jest nadzieja na powstanie optymalnego dla miasta systemu przyrodniczego. Projekt ten ma trudne do waloryzowania zadanie ponieważ ratuje pozostałości naturalnych i nieco przekształconych ekosystemów wplatając w nie renaturalizowane doliny rzeczne i tereny zbiorników wodnych. [il. 4] ronment (full of greenery, basins or watercourses) provides, influencing the microclimate and giving man an unique chance for a healthy life. concept of sorts) - connecting varied natural parts of the city as well as providing protection. One of the oldest (still not important enough) is The Green Circle of Tradition and Culture, which was tial Building Plan. The most important part was the tage. The idea was to connect the existing park and city green to historic factories and tenements, which are being restored. The included areas were: Manufaktura, Politechnika Łódzka, Księży Młyn or the Mątwiłł Mirecki tenement complex along with Park na Zdrowiu and post-military Brus area. In the future, the Green Treasures of Lodz project, created in 2007 within the framework of The Study of Lodz Conditions and Developmen valleys (18), nature - landscape complexes (13), forest complexes (4). Another project - Blue and all green places which serve Lodz inhabitants. It will be a complete nature restoration project. It will be connected to other plans for recreation spaces and improvement of the quality of life in ers, which flow into three basins: Bzura (Bzura
In Lodz a complex program is being instituted (a designed in 1993 along with The City of Lodz Spa protection of the natural, historic and cultural her Destinations. It was supposed to contain: river Green Net of integrated forests, recreational areas the city. In Lodz there are watercourses and riv-
Jakie stoją przed nami zadania aby zachować, rozbudować wienia warunków życia w aglomeracji? Najpotrzebniejsze jes podjęcie decyzji o bezwzględnej ochronie terenów otwartych, ochronie dolin rzecznych w ramach powstających dokumentów planistycznych, jedynie bowiem zapisy planów jako akty prawa miejscowego daja szanse na realizacje tych pieknych idei. Idei budujacych pomost dla projektów budujemy dzisiaj tódź dla przyszłych pokoleń.

Mikroklimat budowany przez cieki w mieście jest wyjatkowo korzystnym dziataniem dla zdrowi i żcia populaci miejkich. Wywera on wplyw a miedzy inymi spownosc unystowa fizczna ludzi. Pomaga poprawic wydanośc w procy czy fiz tez stabilizuje gosodar ne znaczenie ma sposob planowania urbanistycznego, to

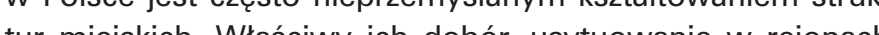

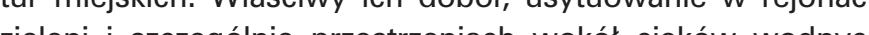
zieleni i szczegónie przestrzeniach wokot cieków wodnych izbiornikow decyduje o tym jak odbieramy przestrzen miasta. Szczegölnie racjonalne gospodarowanie istniejącymi zasobami i przekształcanie rejonow najcenniejszych przyrodniczo, wpływających na mikroklimat jest często niedoceniane przez społecznosci i władze. Walka, dbanie o srodowisko naturaln zrównoważony rozwoj o który tak ostatnio walczą świadom jego znaczenia srodowska architektów, ekologów, hydrologow, wydaje się rzeczą nadrzędna. Aktualnie možna stwierdzic potrzebę wzmocnienia narzędzi prawnych dla przemyślanej i egzekwowalnej polityki planistycznej, dla prawidłowego funkcjonowania i rozwoju społeczenstwa w przyszłości. Zasoby te są często nie do odnowienia, tracimy zbyt wiele dobrego otoczenia przyrody. Ostatnio tak dyskutowane wartości miast pieszego, są bez takich rejonów i przestrzeni bez przyszłości. Kolejna bardzo ważna przesłanka racjonalnego rozumnego projektowania i egzekwowania w realnym działaniu prze strzennym jest równowaga wód opadowych w mieście. Generalnie wszystkie działania zwiazzane z zachowaniem Btekitno - Zielonej Struktury Missta", równiez projektowa na wo kodz obejmujaca systemy przyrodnicze: pótnatura re wo ka zowierzchiowych, ciéw, wszelkich rowón, cieḱw okresowych, terenow podm mi wedniw ramach oghodow prywaych prydomowych iogrodo dzilkowych daja nam pe i ogrodów dzialkowych dają nam pełna gamę tzw. usług ekosystemowych. Zielen miejska petni istotną rolę $w$ pozyskiwaniu wody z gleby, i uwalnianiu jej w procesie parowania daje to wymierne korzyści. Roślinnośc zwiększa wilgotnośc powietrza i obniża jego temperaturę jak również skutecznie oczyszcza powietrze Są one niezbędne do funkcjonowani fauny i flory środowiska miejskiego, regulują mikroklima w cyklu rocznych wahań pogodowych, na przykładzie Wiednia zapobiegają zalaniom i powodziom, są w koncu wartosciami kulturowymi zawierając walory edukacyjne i oddziałujace swą estetyką szczególnie na standard zycia mieszkańców. Przyroda rejonów rzek i cieków na przykładzie Wiednia, Mainz, czy Łodzi potwierdza ten dar obcowania z pięknem natury. Inicjatywą Unii Europejskiej jest wprowadzenie inicjatywy Mayors Adapt - porozumienia między burmistrzami w spra-
Aniołówka and Zimna Woda), Miazga (Miazga), Ner (Ner, Gatka, Jasier Karolewka, Lodka, Balutka, Jasieniec, Dobrzynka). This project is supposed to connect over 500 ha of area, greenery, cemetaries, allotments and 5 forest complexes: Łagiewniki, Lublinek, Popioły, Zabieniec, Rokicie (1350 ha). Historic and natura monument complexes is another couple of hundred hectares. After many years of construction there is a chance to create an optimal natura system. This project is difficult because it saves what is left of natural and slightly modified ecosystems, integrating restored river valleys and river reservoirs. [ill. 4]

What are the tasks before us, to preserve, expand and fully use the city ecosystem resources to improve the quality of life? The most important decsion is to protect the open areas and river valleys in written form, because only plans (local law acts) provide a chance to make this a reality. This idea builds Lodz for the future generations.

The microclimate created through watercourses in the city is especially positive for health and life of the city population. It improves, among other things, mental and physical efficiency, work activity and body heat management. Urban planning is very important - in Poland it is often not thought through enough. The correct selection of urban structures, setting in the green areas, especially near watercourses and reservoirs influences our perception of the city space. The authorities an communities often do not value reshaping the most vital natural spaces, which influence the $\mathrm{m}$ croclimate. Fighting for the natural environment and a balanced development in which architects, ecologists and hydrologists take part seems to be of primary importance. Presently, there is a need to strengthen legal tools for a well designed and enforced design planning and better operation and development of society in the future. Such resources are often good for only one use, we use up too much of natural environment. Lately there are a lot of discussions about the values of pedestrian cities, which have no future without natura space.

Another very important part of rational design and execution in real space is the balance of rain water in the city. In general, all activities, whic have to do with preserving the "Blue - Green City Structure", also designed in Lodz, including natural systems, such as: half - natural, restored or natural surface waters, reservoirs, ditches, wetlands, private gardens, provide us with a ful range of "ecosystem services". City green has an important role in acquiring water from the ground and releasing it in the process of evaporation which provides real benefits. Plants increase air humidity and lower its temperature as well as effectively cleanse it. They are essential for the ur- 
